\title{
Legal Strength of Consumer Financing Principal Agreements Post The Decision of the Constitutional Court No. 18/puu-xvii/2019
}

\author{
Nasrullah ${ }^{1}$ \\ ${ }^{1}$ Faculty of Law Universitas Pohuwato Jl. Trans Sulawesi No. 147 Marisa, 96266 \\ Email: nasrullahderna114@gmail.com
}

\begin{abstract}
After the Constitutional Court Decision No. 18/PUU-XVII/2019, fiduciary certificates no longer have direct executive power and the determination of promise injuries is not determined unilaterally by financing creditors but based on agreements between creditors and debtors. This certainly has an impact on fulfilling the rights of business actors (creditors) and ignoring binding powers on the principal financing agreement and fiduciary certificate. The purpose of this study is to find out whether the Constitutional Court Decision No. 18 / PUU-XVII / 2019 is contrary to the main agreement of consumer financing, and How the legal strength of the consumer financing agreement after The Constitutional Court Decision No. 18 / PUU-XVII / 2019. The type of research used is a type of normative research with a focus on the statutory approach and the conceptual approach. The results of the study explained that the principal agreement of consumer financing with The Decree no. 18 / PUU-XVII / 2019 there is a conflict (conflict) but only a pseudo conflict (not a textual conflict) because in terms of intent and purpose there is no conflict, but potentially less balance the legal interests of business actors. Constitutional Court Decision No. 18/PUU-XVII/2019 has destabilized the existence of the deed of the principal financing agreement. The minimum limit of proof of the principal financing agreement is not perfect and no longer binding as the law for both parties and the deterioration of the evidentiary value of the deed of the principal agreement and the legal strength of the fiduciary certificate and the principal financing agreement is in the determination of the court. There need to be regulations that regulate sanctions if consumers deliberately delay their obligations to pay credit installments and the need for the participation of community institutions, business actors, and including the government to socialize.
\end{abstract}

Keywords: The Power of law; Principal Financing Agreement; Decree of MK No. 18/PUUXVII/2019 


\section{INTRODUCTION}

The competence of the Indonesian Constitutional Court in the field of Judicial Review is aimed at the testing of the Law against the Constitution both in terms of formal and in terms of material, which is commonly termed by testing constitutionalism. The basis of the Constitutional Court conducts constitutionality testing, found in Article 24C of the 1945 NRI Constitution and further regulated in Article 10 of Law No. 24 of 2003 concerning the Constitutional Court and its amendments to the Law. No. 8, 2011. ${ }^{1}$

Jimmy Asshiddiqie ${ }^{2}$ It further comments that theoretically, the existence of the Constitutional Court was introduced by Hans Kelsen. According to him, the implementation of constitutional rules on legislation can be effectively guaranteed only if an organ other than the legislature is given the task of testing whether a product of the law is constitutional or not, and does not enforce it if according to this organ the product of the law is unconstitutional.

The special organ that controls it (the Constitutional Court) can abolish the entire unconstitutional law, so it cannot be applied by other organs. Whereas if an ordinary court has the competence to test the constitutionality of a law, it may only be in the form of refusing to apply it in a concrete case when stating that the law is

\footnotetext{
${ }^{1}$ Jurnal Konstitusi, Vol. 1, No, 1, November 2012, Nurul Qamar, Kewenangan Judicial Review Mahkamah Konstitusi, h.3

2 Jimly Asshiddiqie,2005, Model-Model Pengujian Konstitusional di Berbagai Negara, Konstitusi Press, Jakarta
}

unconstitutional while other organs are still required to apply it. ${ }^{3}$

One of the Constitutional Mahkama Rulings that is the result of Judicial Review is The Decree No. 18 / PUU-XVII / 2019 which is a legal prodak born from the Mahkama Constitution which is the same degree of hierarchy as the law. The court's decision is an ideal legal prodak in the sense that it is very good in regulating the life of legal subjects in its position as legal certainty, but if applied in legal facts does not give birth to its problems and is considered less fair, because not all consumers understand the purpose of the MK Ruling.

As proof of the holder of the fiduciary guarantee rights, the financing company will receive a fiduciary guarantee certificate. With this Certificate, creditors have the right to sell objects that are the object of fiduciary guarantees on their power if the debtor is injured by a promise. ${ }^{4}$ This is characterized by the inclusion of the words "FOR THE SAKE OF JUSTICE BASED ON THE SUPREME DIVINITY" in the Fiduciary Guarantee Certificate. ${ }^{5}$ After the Decision of MK No. 18 / PUUXVII / 2019, the financing company is no longer allowed to make a direct withdrawal of motor vehicles. This is because Article 15 paragraph (2) of Law No. 42 of 1999 on Fiduciary Guarantee regulates related to the phrase "executive

3 Arend Lijphart,1999, Patterns of Democracy Government Foruns and Performance in Thirty Six Countries, Yale University, London.

4 Pasal 15 ayat (3) UU No. 42 Tahun 1999

${ }^{5}$ Pasal 15 ayat (1) UU No. 42 Tahun 1999 
power" and the phrase "equal to the court's ruling of permanent legal force" is considered contrary to the Indonesian Constitution of 1945. With the results of the judicial review application decision, of course, the financing company is not allowed to make a direct vehicle recall but must ask for the determination of the court first, unless the consumer voluntarily submits the vehicle which is the object of jamming that has been transferred fiduciary. The withdrawal of motor vehicles is done based on default on the principal agreement made by the financing consumer. The agreement/contract certainly has the same legal force as the law for those who bind themselves to the agreement/contract, as stipulated in Article 1338 paragraph (1) of the Civil Code. It is also known as the Pacta Sunt Servanda principle. Pacta Sunt Servanda principle or also called the principle of legal certainty. This principle relates to the consequences of the agreement. Pacta ${ }^{6}$ Sunt Servanda is the principle that judges or third parties must respect the substance of contracts made by the parties, as is the law. They should not intervene in the substance of contracts made by the parties.

The legal relationship between consumers and consumer financing companies is born from the principal agreement of consumer financing which is then with a fiduciary transfer of rights agreement which is an accessory

\footnotetext{
6 Salim, 2009. Contract Law Theory and Contract Preparation Techniques, Sinar Grafika, Jakarta. h. 10
}

agreement (follow-up). The principal agreement of consumer financing is certainly the substance of the consumer's obligation to make payment of installments of financing credit every month on time. And if not, then the consequence is a fine and does not rule out the possibility of ending in a vehicle recall. As for vehicles purchased with the consumer financing system and have been transferred in a fiduciary manner, then of course when consumers (debtors) default and the issue of fulfilling the company's execution rights refers to the Constitutional Court Decision No. 18 / PUU-XVII / 2019 whose position is equivalent to the law and does not refer to the principal agreement of consumer financing and fiduciary certificate. So that the fiduciary certificate is only a complement to administration because it no longer has direct executory power. Similarly, the phrase "promise injury" is considered unconstitutional if it does not mean that "the existence of a promising injury is not determined unilaterally by the creditor but based on an agreement between the creditor and the debtor or based on a legal effort that determines the existence of a promising injury". With the ruling, the fiduciary guarantee certificate will lose the same executive power as the court's decision that has obtained legal force if it does not meet the first requirement, there is an agreement on the injury of the promise (wanprestasi), and the two debtors voluntarily submit the object of the guarantee. ${ }^{7}$ Thus, the

\footnotetext{
${ }^{7}$ Journal of Eko Surya Prasetyo, 2020, Implications of The Constitutional Court Decision No. 18/PUUXVII/2019 On The Execution of Guarantee
} 
fulfillment of the right for consumer financing business actors as creditors needs to be assessed from the principal agreement of consumer financing. Although the issues are different, it gives birth to a gap between the Constitutional Decree No. 18 / PUU-XVII / 2019 and the main agreement of consumer financing. This has an impact on the fulfillment of the rights of business actors sourced from the basis of consumer financing principal agreements and fiduciary certificates that are difficult to realize under the principal financing agreement.

\section{Problem Statement}

From the background above, the author pulls a problem formulation, namely:

1. Does the Constitutional Mahkama Decree No. 18/PUU-XVII/2019 be contrary to the principal agreement of consumer financing in terms of fulfilling the rights of financing businesses?

2. What is the legal power of the consumer financing agreement after Constitutional Court Decision No. 18/PUU-XVII/2019?

\section{Research Method}

The type of research that the author used in this study is doctrinal /normative legal research. For normative legal research that only regards secondary data by tracing primary legal materials, secondary legal materials, and tertiary

Institutions, Reflections of Law, Faculty of Law, Satya Wacana Christian University legal materials. The materials are systematically arranged, studied, then drawn a conclusion about the problem studied. The approach used is the statute approach and the conceptual approach.

\section{DISCUSSION}

1. Constitutional Court Decision No. 18/PUU-XVII/2019 Is Contrary to The Principal Agreement of Consumer Financing in The Fulfillment of The Rights of Financing Business Actors.

The agreement has binding powers like the law for both parties or commonly also called the pacta sunt servant principle. The legal principle is Basic and abstract thinking compared to the norms of law and the rule of law itself. As for legal norms according to Bruggink in the book entitled Repleksi About Law written that legal norms are basically in order, some are in the form of prohibitions, some are in the form of permits, and the tone is also in the form of dispensation. Prof. Achmad Ali's book entitled ${ }^{8}$ Strengthening Legal Theory explained that the principles of law and legal norms can only be applied after being transformed into the rule of law. ${ }^{9}$

Pacta sunt servanda is an abstract basic thought contained in concrete law or outside the rule of concrete law which is the basic thought of all types of legal engagements, including in this case consumer financing agreements and

\footnotetext{
${ }^{8}$ Bruggin, 2012. Reflections on the Law. Aditya Bakti Image, Bandung, h. 100

9 Achmad Ali. 2012. Menguat Teori Hukum dan Teori Peradilan, Kencana. Jakarta, h. 176
} 
fiduciary guarantees. Financing with a consumer financing system is one way to be able to divert vehicles on a fiduciary basis even though the vehicle is still in credit. Buying a vehicle on credit with a consumer financing system is three legal subjects involved: suppliers, financing companies, and consumers themselves. The relationship of rights and obligations is that consumer financing companies are obliged to finance the purchase price of goods needed by consumers and pay them in cash to suppliers. Consumers are obliged to pay in installments to consumer financing companies, and suppliers are obliged to hand over goods to consumers. ${ }^{10}$

Vehicles purchased by way of credit, the essence are not fully owned by consumers because they have not paid off their credit installments. So it is not yet appropriate for the vehicle to be used as an object of fiduciary guarantee, because the definition of fiduciary in Article 1 number 1 UUJF is written that:

"Fiduciary is the transfer of the property rights of an object based on trust on the condition that the object whose property rights are transferred remains in the possession of the owner of the object"11

The phrase "transfer of property rights" of course the subject that is meant to transfer ownership rights here is the consumer. So logically, how can consumers transfer ownership rights

\footnotetext{
${ }^{10}$ Abdulkadir Muhammad and Rilda Murniati. 2000. Legal Aspects of Financial Institutions and Financing. Aditya Bakti's image. Bandung. h. 246

11 Pasal 1 angka 1 Undang-Undang No. 42 Tahun 1999 Tentang Jaminan Fidusia
}

while consumers have not fully 100\% own the vehicle because it has not paid off the installment of the motor vehicle loan. So ideally is a vehicle that has paid off $100 \%$ which can be used as a fiduciary guarantee object.

However, in a consumer financing system different from other financing systems, when consumers have paid the first installment in the consumer financing system, vehicle ownership has switched to consumers. According to Budi Rachmat, consumer financing is the ownership of goods/objects of financing is in consumers who are then transferred fiduciary to consumer financing companies. So that the basic guarantee is fiduciary in the form of goods financed by consumer financing companies where all goods ownership documents are controlled by consumer financing companies ${ }^{12}$ (fiduciary transfer of ownership)until the last installment is repaid.

The convenience offered by financing companies with consumer financing systems is not as easy as in efforts to fulfill their rights that must be obtained from the consumer. Economic reasons and efforts to improve the welfare of the community are the reasons for the existence of financing companies present in the regions. However, economic reasons are also sometimes the cause of disputes between financing

12 Grace. 2002. Multi Finance: Rent For Business, Factoring, Consumer Financing. Novindo Pustaka Mandiri. Jakarta. h. 137 
companies and debtors (consumers) of financing. The birth of the dispute between the two parties is none other than because the parties both feel they have the right to a vehicle purchased with the consumer financing system itself.

The author considers that in a position as a financing business actor like this, it is certainly not easy. Because the company has to face potential losses, so it needs good management of the company, careful, and apply the precautionary principle, both before the legal bond between the financing company as a business actor and vehicle loan debtors as consumers. Various consumer characters are certainly also the basic potential for disputes, so that if the employees of business actors do not understand the character or commit careless actions, then it can be a legal problem that is not only from the aspect of civil, but can cause criminal law problems.

Billing and asking for information related to the delinquent payment of debtors is not an easy thing for the company, this is in addition to the character factor of the debtor, also because of the understanding factor if the debtors related to the constitutional court's own decision. Customers in this case the debtor of consumer financing are misguided related to the Constitutional Court Decision No. 18 / PUU-XVII / 2019, they consider that if the company makes a withdrawal without any determination from the court, then it is considered an unlawful act and included in criminal cases. So that these arguments are often the reason for debtors not to give up motor vehicles that are in their control outside of economic reasons and this certainly makes it difficult for creditors if there must be a promise injury agreement.

The decision of MK No. 18/PUUXVII/2019 also includes social engineering tools and at the same time as a social function. However, if consumers still have a mistaken understanding of The Constitutional Court Decision No. 18 / PUU-XVII / 2019, then it can be said that the MK Verdict does not function properly as a tool of social design and control functions. The birth of the $\mathrm{Mk}$ Ruling, none other than because the recall of vehicles is directly considered to violate the constitutional rights of consumers and includes seizing consumer vehicles. So that the vehicle recall must be determined by the court first.

In UUJF no article regulates and emphasizes that consumers (debtors) are obliged to pay their credit insurance on time because it is regulated in the substance of the financing contract which is the principal agreement. While the Decree of Mk No. 18 / PUU-XVII / 2019 only corrects articles related to the problem of execution of fiduciary guarantee objects but does not regulate related to consumer obligations (debtors) so that there is no default and execution. The author stated so that there is strengthening for the fulfillment of the rights of business actors contained in the principal agreement of consumer financing. 
In this case, it is as if there is a debate regarding the principal alliance and the fiduciary perikarya. Thus giving birth to legal issues, is the legal power of the fiduciary transfer agreement stronger than the principal agreement of consumer financing? The main agreement in this financing is the Consumer Financing Agreement, while the assessor agreement (its follow-up) is the transfer of fiduciary rights to the financing company. If the consumer does not carry out his obligations as in the principal agreement, whether the business actor is not entitled to the object of the fiduciary guarantee. Consequently, something that the tree should take precedence over the non-tree. Consumers do not carry out the obligation to pay installments, then of course it will soften their rights as consumers because the rights and obligations always go hand in hand.

The decision of Mk No. 18/PUU$\mathrm{XVII} / 2019$ is the result of judicial review in Article 15 of Law No. 42 of 1999 on Fiduciary Guarantee whose position is equivalent to the law. For the basic legal consumer financing system is the presidential decree of the Republic of Indonesia Number 61 of 1988 concerning financing institutions and the Decree of the Minister of Finance of the Republic of Indonesia Number: 1251 / KMK.013 / 1988 concerning the Provisions and Procedures for the Implementation of Financing Institutions which were later amended and refined by the Decree of the Minister of Finance No. 468 of 1995 and also the Civil Code. So that these four legal bases are the basis of business activities with the consumer financing system and also at the same time become the basis of the consumer financing agreement itself.

Hierarchically, Constitutional Court Decision No. 18/PUU-XVII/2019 has the same position as the law instead of Jurisprudence, because the law contains the results of judicial review of Law No. 42 of 1999 on Fiduciary Guarantee. Thus the legal basis of the consumer financing principal agreement has a more lace position compared to Mk Decree No. 18 / PUU-XVII / 2019. Although each agreement has binding powers such as the law as in Article 1338 paragraph (1) of the Civil Code or commonly also referred to as the pacta sund servanda principle, it is lexed generalis while The Decree of MK No. 18 /PUU-XVII /2019 is lexed specialis. Thus the decision of MK No. 18 / PUU-XVII / 2019 in addition to superior lex is also lexed specialized related to

fiduciary problems when compared to the nature of the principal financing agreement. Thus it can be understood that the juridical takeoff of fiduciary transfer of ownership rights is stronger than the juridical takeoff of the principal consumer financing agreement. Thus, textually of course there is no conflict inverting and horizontal, but in its application has the potential to give birth to conflict, because Decree no. 18 / PUUXVII / 2019 does not balance the legal interests of business actors and tends to strengthen the position of consumers who are default. 


\section{The Legal Power of Consumer Financing Agreement After The Decree of Mk No. 18/PUU- XVII/2019}

Related to the phrase "power of law" of the principal agreement, the author divides it into 2 (two) namely First, the power of proof with the evidentiary value is perfect and binding. Second, provide legal protection. The truth of the content and the statements contained in it are perfect to stand alone and bind the parties to what is described in the deed of agreement and also binding to the judge should make it the basis of perfect facts and sufficient to take a verdict on the resolution of the disputed case. In addition, any agreement/contract document may provide legal protection for the rights of both parties under the limitations of their rights. Thus every deed must have the power of law both in terms of the power of proof and in terms of legal protection. 13

In addition to legal protections born from the agreement, legal protection there are also laws and regulations and also the constitutional court's decision of judicial review results. The nature of this legal protection is fixed and some are dynamic. What is meant by the protection of laws that are fixed in applicable laws and regulations, although sometimes the laws and regulations change the results of judicial review from the Constitutional Court or the Supreme Court. For the protection of the law that is dynamic itself, namely in the form of efforts made by law enforcement itself for the realization of the purpose of the law itself.

Legal problems are not only born because of unlawful acts or because of people who feel aggrieved but legal problems are also born from the legal basis that becomes the rail of legal certainty to achieve the legal goal itself. So that parties who feel aggrieved by the certainty of the law itself, are entitled to apply for judicial review. As for legal problems born from disputes or the existence of parties who feel aggrieved, they have the right to file a lawsuit to the Court.

A dispute is essentially a rights dispute between the two parties. One party feels aggrieved by the other, while the other feels entitled to defend what it thinks is their right. In addition, efforts to get legal protection of what is considered the right of the subject of law can also be done by applying to the court. The request referred to here there are 2 (two) namely, First the application without dispute. Second, request judicial review against written legal grounds that are considered contrary to a person's constitutional rights.

The author focuses on the protection aspects of the law with the efforts of judicial review application to the Constitutional Court of Law No. 42 of 1999 on Fiduciary and the right for financing business actors to obtain legal protection after the birth of

\footnotetext{
${ }^{13}$ M. Yahya Harahap, 2012, Civil Procedure Law, Sinar Grafika, Jakarta, h.545
} 
Constitutional Court Decision No. 18/ PUU-XVII / 2019. Of course, the Constitutional Court before deciding the application for judicial review of Law No. 42 of 1999 on Fiduciary Guarantee must consider legal protection between both parties, not just the applicant's legal protection. So that the MK verdict is a scientific verdict from the aspect of legal science.

The constitutional court's decision is a final and binding ruling, but not immune from criticism and suggestions from the academic aspect. Thus there is still a wide-open opportunity to test it academically. This is none other than because every decision of the judiciary must be able to provide the spirit of justice for both parties, although it is not the same scale because the demands of justice do not always have to be the same.

The Constitutional Court's decision No. 18/PUU-XVII/2019, has received criticism in essence that the Constitutional Court Decision No. 18/PUU-XVII/2019 is considered to be less than balanced by the rights of financing businesses. This is none other than because the financing business is no longer allowed to carry out executions directly(para te execution), but must be through an application from the district court, so that the legal power of the Fiduciary Guarantee Certificate is no longer equivalent to a court ruling with permanent legal force.

In addition, provisions related to the time of appointment injury must be met and agreed upon in advance with the consumer. So that it is not necessarily when the consumer is in arrears, the company has the right to carry out executions directly. Although in practice it is not like that done by the company. In addition, the process of withdrawal and execution becomes longer and also convoluted. Fundamental differences related to the problem of execution of fiduciary guarantee objects.

Looking at the comparison of Law No. 42 of 1999 on Fiduciary Guarantee with Constitutional Court Decision No. 18 / PUU-XVII / 2019 is the most basic issue of execution. In essence, the financing business can no longer make withdrawals directly and the time to be able to be cpakpak promised injury must be an agreement first.

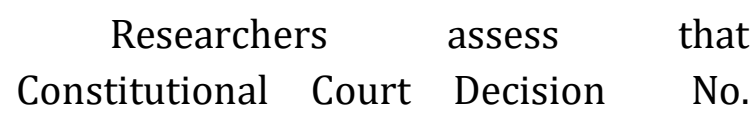
18/PUU-XVII/2019 is part of the renewal of civil law, namely the fiduciary guarantee law. One of the rights of property is the right to guarantee objects. One type of legal engagement in the law of guarantee is the fiduciary Damian. Fiduciary guarantee engagement is the accessory (follow)'s Pelikan from the principal engagement. In the sense of the alliance, the tree can stand without the accessory perikarya. So there will be no access alliance if there is no principal engagement. In the legal contract of motor vehicle financing, the consumer financing contract is the principal engagement, while the transfer of ownership rights in fiduciary is an accesoirengagement. 
The withdrawal of motor vehicles that are in the control of the debtor (consumer), and the end the debtor objects and sues and arrives at the judicial process and won by the consumer. This happens to the consumer financing business actors who make withdrawals without any determination from the court first and voluntary submission from the debtor.

The above picture is an impact of the Constitutional Court Decision No. 18 / PUU-XVII / 2019 for consumer financing business actors if they make withdrawals without a determination from the court. The judge's ruling that wins the debtor (consumer) is not a wrong thing. Because it is basically by the provisions of the applicable law in this case the MK Verdict.

On the other hand, it is necessary to consider the aspect of justice for financing business actors and the aspect of usefulness in the world of consumer financing business. The consideration is that consumers are considered to have broken the promise that installments are not paid 3 times for example, and it is a violation of the promise on the main agreement that is a consumer financing agreement, while the business actor in making vehicle recalls, first there must be a determination from the court, if making a vehicle recall without any determination from the court, then it is considered an unlawful act.

The existence or not of the determination of the court owned by consumer financing business actors is not a fair benchmark or not the actions of business actors in the introduction of vehicles. The absence of court determination owned by business actors in making vehicle recalls does not mean that the act is an unfair thing. Because the rights of business actors are in the principal engagement of consumer financing agreements and fiduciary transfer of property rights and fiduciary certificates.

The author concluded that Constitutional Court Decision No. 18/PUU-XVII/2019 has destabilized the existence of the deed of the principal financing agreement. So that the minimum limit of proof of the principal financing agreement is not perfect and no longer binding as a law for both parties and cannot provide strong legal protection for the fulfillment of the rights of business actors because of the decline in the evidentiary value of the basic agreement deed without having to be a proof of resistance submitted by consumers. In other words, the legal power of the fiduciary certificate and the deed of the principal financing agreement is in the determination of the court.

\section{CONCLUSION}

Based on the results of the discussion above, it can be concluded that:

The principal agreement of consumer financing with Decree No. 18/PUU-XVII/2019 there is a conflict (conflict) but only a pseudo conflict (not a textual conflict) because in terms of intent and purpose there is no conflict. However, in its application, Decree no. 18 
/ PUU-XVII / 2019 has the potential to reduce the legal interests of business actors and fiduciary transfer of property rights agreements more inclined to strengthen the position of consumers who wanprestasi (broken promises).

Constitutional Court Decision No. 18/PUU-XVII/2019 has destabilized the existence of the deed of the principal financing agreement. So that the minimum limit of proof of the principal financing agreement is not perfect and no longer binding as a law for both parties and cannot provide strong legal protection for the fulfillment of the rights of business actors because of the decline in the evidentiary value of the basic agreement deed without having to be a proof of resistance submitted by consumers. In other words, the legal power of the fiduciary certificate and the principal financing agreement is in the determination of the court.

\section{SUGGESTION}

The researcher's advice after the discussion is as follows:

There need to be regulations that regulate sanctions if consumers deliberately delay their obligations to pay credit installments when on the other hand consumers can afford to pay credit installments.

To increase public understanding related to consumer financing issues, it is necessary to participate in community institutions, business actors, and including the government to socialize related to consumer financing issues.

\section{Reference:}

\section{Books}

Abdulkadir Muhammad dan Rilda Murniati. 2000. Segi Hukum Lembaga Keuangan dan Pembiayaan. Citra Aditya Bakti. Bandung

Achmad Ali. 2012. Menguat Teori Hukum dan Teori Peradilan, Kencana. Jakarta

Amiruddin dan Zainal Asikin. 2010. Pengantar Metode Penelitian Hukum. Rajagrafindo: Jakarta

Arend Lijphart. 1999. Patterns of Democracy Government Forums and Performance in Thirty Six Countries, Yale University, London.

Budi Rahmat. 2002. Multi Finance: Sewa Guna Usaha, Anjak Piutang, Pembiayaan Konsumen. Novindo Pustaka Mandiri. Jakarta

Bruggin, 2012. Refleksi Tentang Hukum. Citra Aditya Bakti, Bandung

Jimly Asshiddiqie,2005, Model-Model Pengujian Konstitusional di Berbagai Negara, Konstitusi Press, Jakarta

M. Yahya Harahap, 2012, Hukum Acara Perdata, Sinar Grafika, Jakarta

Salim, 2009. Hukum Kontrak Teori dan Teknik Penyusunan Kontrak, Sinar Grafika, Jakarta

\section{Journal}

Jurnal Konstitusi, Vol. 1, No, 1, November 2012, Nurul Qamar, Kewenangan 
Judicial Review Mahkamah Konstitusi

Jurnal Refleksi Hukum, Vol. 5 No. 1, Eko Surya Prasetyo, 2020, Implikasi Putusan Mahkamah Konsitusi Nomor 18/PUU-XVII/2019 Terhadap Pelaksanaan Eksekusi Lembaga Jaminan, Fakultas Hukum Universitas Kristen Satya Wacana

\section{Law and Regulations}

Undang-Undang No. 42 Tahun 1999 Tentang Jaminan Fidusia

Putusa Mahkamah Konstitusi No. 18/PUU-XVII/2019

Keputusan Presiden Republik Indonesia Nomor 61 Tahun 1988 Tentang Lembaga Pembiayaan

Keputusan Menteri Keuangan Republik Indonesia Nomor: 1251/KMK.013/1988 Tentang Ketentuan dan Tata Cara Pelaksanaan Lembaga Pembiayaan yang kemudian diubah dan disempurnakan dengan Keputusan Menteri keuangan No. 468 Tahun 1995 